\title{
Tingkat keberlanjutan terhadap aspek pengelolaan sumur tua secara tradisional di Bojonegoro Jawa Timur
}

\author{
Ahmad Kurnain ${ }^{1}$, Yusni Ikhwan Siregar ${ }^{2}$, Sri Indarti ${ }^{3}$, Suwondo ${ }^{4}$ \\ 1,2 Program Studi Doktor Ilmu Lingkungan Program Pascasarjana Universitas Riau \\ ${ }^{3}$ Fakultas Ekonomi dan Bisnis Universitas Riau \\ ${ }^{4}$ Program Studi Pendidikan Biologi FKIP Universitas Riau \\ *Correspondent email : ahmad_nain28@yahoo.com
}

Diterima: 28 Januari 2021| Disetujui: 28 April 2021 | Diterbitkan: 30 April 2021

\begin{abstract}
This study aims to determine the sustainability status of the Re-Opening Oil Wells of Bojonegoro Regency, East Java, Indonesia. The method used in this research is Multidimensional Scaling analysis which is implemented using Rap-Re-Opening Oil Wells software. Existing status of Wells Bojonegoro Re-Opening Oil Sustainability Less Sustainable with the weighting value of each dimension is $34.56 \%, 39.73 \%, 45.25 \%, 37.90 \%, 57.00 \%$. The strategy to increase the addition of status values from the 5 dimensions of the Sustainability Index, evaluated only one dimension that is sustainable with a fairly good status. The results obtained from the improvement scenario obtained by the respective percentage figures as follows; Ecology 41.44\%, Economics $61.62 \%$, Social and Culture $45.25 \%$, Technology $42.02 \%$, Institutional $61,29 \%$. Thus the strategy to increase sustainable status can be improved by the Oil Wells Rap-Re-Opening Method.
\end{abstract}

Keywords: Dimension Improvement; Status Enhancement; Sustainable Implementation

Pertumbuhan ekonomi dan pendapatan per kapita merupakan indikator yang paling umum digunakan untuk mengukur kesejahteraan. Penelitian tentang ekonomi tradisional fokus pada pertumbuhan ekonomi dan faktor-faktor ekonomi (Huang \& Ho, 2017). Perubahan ukuran capaian keberhasilan pembangunan ditandai dengan adanya redefinisi keberhasilan pembangunan terjadi pada tahun 1990an. Indikator Gross Domestic Product (GDP) tidak dapat dianggap sebagai ukuran yang dapat menggambarkan kesejahteraan dan bahwa kualitas kehidupan berupa pemenuhan kebutuhan dasar manusia yaitu pendidikan, kesehatan dan pendapatan sejatinya merupakan ukuran keberhasilan pembangunan sedangkan yang menjadi penentu utama tingkat kemiskinan adalah kapabilitas untuk berfungsi (capability to function) (Todaro \& Smith, 2011a; van den Bergh \& Kallis, 2012).

Todaro \& Smith (2011a). Seiring dengan berjalannya waktu, maka pembangunan ekonomi yang biasa diukur dengan pertumbuhan ekonomi yang dibarengi dengan pemenuhan kebutuhan sosial masih harus diselaraskan dengan perhatian terhadap lingkungan (Rasic, et al., 2012). Kualitas lingkungan mempengaruhi dan dipengaruhi oleh pembangunan ekonomi (Todaro \& Smith, 2011b).

Mulai disadari bahwa semakin banyak masalah yang dihadapi dunia seperti perubahan iklim, semakin berkurangnya keanekaragaman hayati, kemiskinan, krisis kepercayaan dan lain-lain (Broman \& Robert, 2015). Pembangunan berkelanjutan merupakan perspektif baru pembangunan yang berkomitmen memberikan kontribusi untuk masa depan (Walkowiak, 1996). Oleh karena itu diperlukan ukuran keberhasilan pembangunan sebagaimana diuraikan diatas yang selanjutnya dikenal sebagai tujuan pembangunan berkelanjutan sustainable development goals SDGs yang pelaksanaannya biasa diukur pada lingkup suatu wilayah kerja.

Sumur tua atau sumur marginal adalah sumur-sumur yang dianggap sudah tidak produktif atau tidak ekonomis jika dikelola dengan teknologi konvesional. Kategori sumur tua tersebut adalah sumur minyak yang di bor sebelum tahun 1970 berdasarkan Peraturan Menteri Energi dan Sumberdaya Mineral Nomor 01 Tahun 2008 dan pernah diproduksi selama kurun waktu tertentu. Sumur-sumur tersebut terletak di lapangan-lapangan migas yang tidak diusahakan dari suatu wilayah kerja yang telah terikat Kontrak Kerja Sama oleh Kontraktor. Mark J. Et al., (2008). Sumur dibor untuk mengeksplorasi, menggambarkan dan menghasilkan reservoir hidrokarbon. Di akhir masa manfaatnya, sumur bor akan ditinggalkan secara permanen dalam proses yang disebut Plugging and Abandonment (P\&A). Tujuan dari P\&A adalah untuk mencegah migrasi fluida dari lubang sumur dan menetapkan penghalang permanen ke formasi geologi yang ada. 


\section{ZONA}

Jurnal Lingkungan

ISSN : 2502-6496 (Print) | 2502-6496 (Online)

Kegiatan penambangan minyak tradisional dapat dikategorikan dalam kegiatan ekonomi kerakyatan yang pada kenyataannya merupakan suatu "jaring pengaman sosial" bagi kelompok masyarakat bawah yang menggantikan ketiadaan pelayanan dasar yang semestinya disediakan oleh pemerintah. Sebagian masyarakat pada kegiatan ini berada dalam tahapan bertahan hidup dan menjadikan aktivitas yang dijalaninya sebagai persiapan untuk masuk kedalam kegiatan ekonomi lain yang lebih. Konteks pelaksanaan yang berbasis sumberdaya alam bertolak belakang dengan prinsip keberlanjutan namun bila kita pandang dari sudut model pengelolaanya bisa ditentukan dan diukur dalam katagori atas tingkatan berkelanjutan.

Dalam konteks keberlanjutan model pengelolaan dapat dilihat sebagai pengelolaan sumberdaya secara maskimal. Ini semua tak terlepas dari tatanan cara mengelola mulai dari tahapan tatanan secara ketentuan, pengelompokan dalam tahapan sumberdaya alam, tata kerja dilapangan dan tahapan pengolahan hingga menjadi potensi sumberdaya yang menghasilkan bagi masyarakat penambang. Untuk mendapatkan hasil yang maksimal dalam pengelolaan perlu dilakukan langkah langkah dalam tahapan pengelolaan baik itu secara teknis, hukum, dan manajemen pengelolaan.

Lingkup penelitian yang di telaah dalam penelitian ini meliputi dari berbagai aspek yang berkorelasi langsung dengan kegiatan pengelolaan sumur tua minyak bumi antara lain adalah; aspek ekologi, ekonomi, sosial budaya, teknologi, dan kelembagaan. Analisis model dan tingkat keberlanjutan pengelolaan dari beberapa aspek dilakukan dengan mengacu pada data-data yang ada baik data primer naupun data skunder yang didapat dari hasil survei dilapangan dan diperkuat dengan data-data hasil wawancara dengan para ahli dan pelaksana kegiatan dilapangan dimana tempat kegiatan penambangan dilakukan. Lokasi kegiatan penelitian ini dilakukan bertempat di Lapangan minyak Wonocolo dan Dandangilo Kedewan Bojonegoro Provinsi Jawa Timur Indonesia, yang merupakan Wilayah Kerja Pertambangan milik Pertamina EP pada Blok Cepu terutama untuk sumur-sumur tua yang penambangannya di kelola oleh Masyarakat.

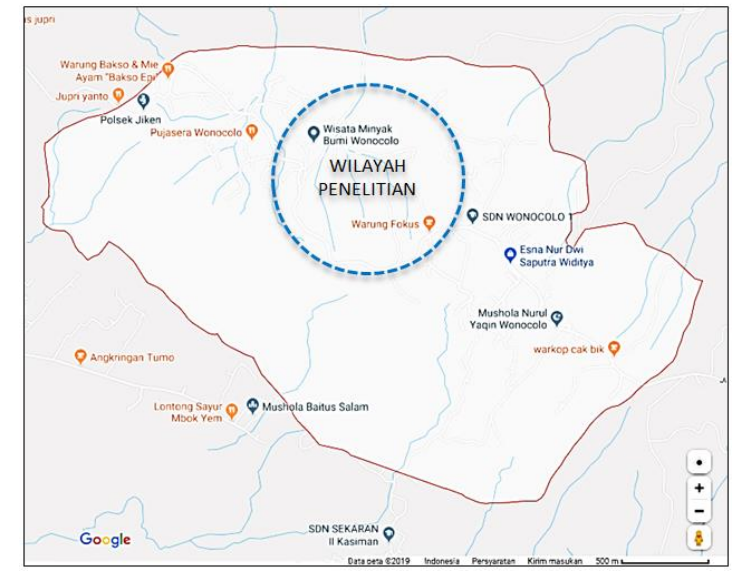

Gambar 1. Peta lokasi penelitian

\section{METODE PENELITIAN}

\section{Analisis Keberlanjutan Dengan Multidimensional Scaling}

Untuk mengetahui status keberlanjutan dari upaya pemanfaatan sumur tua minyak bumi di Desa Kedewan dan Wonocolo, dilakukan analisis keberlajutan terhadap kelima dimensinya dengan menggunakan perangkat lunak RAPFISH (dikembangkan oleh Kavanagh dan Pitcher, 2004). Kemudian diperkuat dengan uji MONTE CARLO dan selanjutnya untuk mengetahui atribut yang paling berpengaruh sebagai faktor pengungkit maka dilakukan analisis $L E V E R A G E$.

J. F. Willis et al., (1969) Simulasi Monte Carlo bukanlah pengganti konstruksi model teoretis yang tepat, juga bukan pengganti desain eksperimental dan analisis statistik yang tepat. Sebaliknya simulasi Monte Carlo adalah metode melakukan eksperimen pada model yang diekspresikan secara fungsional. Rita Parmawati, (2019) Kerangka mata pencaharian berkelanjutan dibagi menjadi lima komponen modal: manusia, alam, fisik, keuangan, dan sosial. Analisis keberlanjutan dilakukan dengan menggunakan pendekatan Multi-Dimensional Scaling (MDS) dengan Rapid Appraisal Techniques for Fisheries (Rapfish). 


\section{ZONA}

Jurnal Lingkungan

ISSN : 2502-6496 (Print) | 2502-6496 (Online)

Tony J.Pitcer, (2001). Rapfish (Rapid Appraisal for Fisheries) adalah teknik penilaian cepat multi-disiplin baru untuk mengevaluasi kelestarian komparatif perikanan. Untuk tujuan analisis ini, perikanan dapat didefinisikan secara fleksibel sebagai entitas dengan cakupan yang luas menempatkan sesuatu pada urutan atribut yang terukur dengan Multi Dimensional Scalling (MDS). MDS sendiri pada dasarnya merupakan teknik statistik yang mencoba melakukan tranformasi multidimensi ke dalam dimensi yang lebih rendah (Fauzi dan Anna, 2005). Setiap dimensi mempunyai atribut atau atribut yang terkait dengan sustainability.

Data-data kualitatif yang bukan berwujud angka-angka tetapi kata-kata berupa data Sosial Budaya, Teknologi, Kelembagaan dan Peraturan dikumpulkan dengan cara observasi, wawancara. Untuk mendapatkan data dan informasi kualitatif dalam penelitian ini dilakukan dengan wawancara mendalam tidak terstruktur yakni dengan mengajukan pertanyaan-pertanyaan yang mengundang jawaban dan komentar secara bebas dimana pandangan sikap pendapat dan keyakinan subyek tidak dapat dipengaruhi oleh peneliti. Indeks keberlanjuatn pengelolaan pertambangan minyak pada sumur tua (Re-Opening Oil Wells) mencakup 5 Dimensi dengan masing masing dimensi terdapat 8 atribut yang merupakan atribut keterwakilan dari masing masing dimensi. Selanjutnya atribut -atribut ini diberi nilai berdasarkan informasi responden yang valid dan standar barometer ketentuan pemerintah untuk selanjutnya merupan data yang akan diolah dalam Analisis Rap-Re-Opening Oil Wells.

Dengan menyatakan defenisi operasional, dapat diketahui baik buruknya konsep tersebut dengan kriteria dan atribut-atribut dapat disusun dalam urutan sebagai berikut;

Tabel 1. Keriteria Penilaian Atribut Keberlanjutan

\begin{tabular}{|c|c|c|c|c|}
\hline \multirow[b]{2}{*}{ No } & \multirow{2}{*}{$\begin{array}{c}\text { Atribut } \\
\text { Pengelolaan }\end{array}$} & \multicolumn{3}{|c|}{ Kelompok } \\
\hline & & Buruk & Baik & Nilai \\
\hline 2 & & & & \\
\hline 3 & & & & \\
\hline 4 & & & & \\
\hline 5 & & & & \\
\hline 6 & & & & \\
\hline 7 & & & & \\
\hline 8 & & & & \\
\hline
\end{tabular}

Kemudian di dalam penilaian skor dari masing-masing atribut dianalisis secara multidimensi untuk menentukan satu atau beberapa titik yang mencerminkan posisi keberlanjutan model pertambangan minyak rakyat pada sumur tua yang dikaji relative terhadap dua titik acuan yaitu titik "baik" ("good") dan titik "buruk" ("bad"). Untuk memudahkan ordinasi Rap-Re-Opening oil wells ini menggunakan perangkat lunak modifikasi Rapfish.

Selanjutnya format tabel tersebut dipergunakan untuk dimensi lainnya dengan menyesuaikan atribut-atribut yang sesuai menurut masing masing dimensi. Nilai ini merupakan nilai indeks keberlanjutan model pertambangan minyak rakyat pada sumur tua yang dilakukan oleh masyarakat penambang di desa Wonocolo Bojonegoro saat ini. Ilustrasi hasil ordinasi yang menunjukkan nilai indek keberlanjutan dari sistem yang dikaji diperlihatkan pada Gambar 2

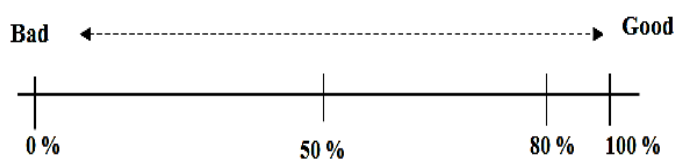

Gambar 2. Bobot Skala Ordinasi Data Pertambangan Minyak Rakyat Pada Sumur Tua Bojonegoro Jawa Timur

Analisis ordinasi ini selain digunakan untuk satu dimensi juga digunakan untuk beberapa dimensi dengan memasukkan semua atribut dari dimensi yang dimaksud. Hasil analisis akan mencerminkan seberapa jauh status keberlanjutan antar dimensi dapat dilakukan dan divisualisasikan dalam bentuk diagram layang-layang (kite diagram) seperti dalam Gambar 3. 


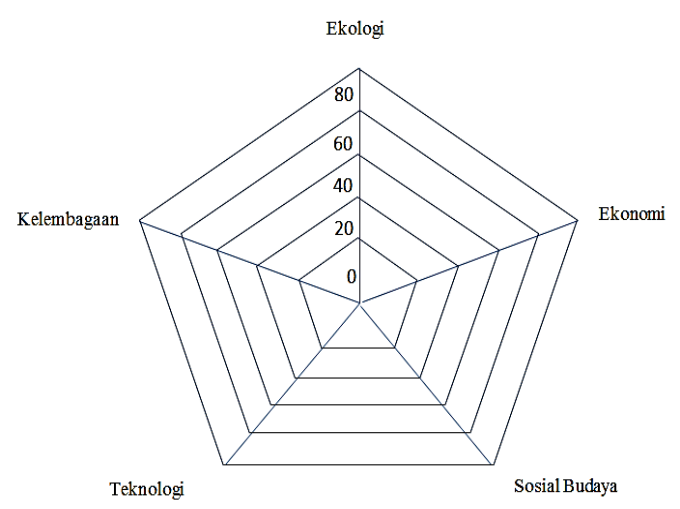

Gambar 3. Bentuk Diagram Layang (kite diagram) Keberlanjutan Pertambangan Minyak Rakyat Pada Sumur Tua Wonocolo Bojonegoro Jawa Timur.

\section{HASIL DAN PEMBAHASAN}

\section{Analisis Keberlanjutan Pengelolaan}

Berdasarkan hasil analisis penilitian dilapangan yang dilakukan secara komprenshif dengan melakukan beberapa cara untuk mendapatkan informasi dari narasumber, baik itu dari masyarakat penambang, pedagang, aparatur pemerintah dari tingkat Kabupaten sampai Desa maka dapat ditentukan nilai dan skala atribut dari masing masing dimensi keberlanjutan.

Nilai dan skala masing masing atribut disusun berdasarkan standar yang sudah ditetapkan oleh pemerintah dan berdasarkan di kesepakatan antara pemerintah dengan masyarakat desa Kedewan dan Wonocolo. Setiap atribut terdiri dari dua kategori penilaian yaitu: kelompok baik (b) atau buruk (Bk) dan diberi nilai (n)

\section{Status Keberlanjutan}

\section{Dimensi Ekologi}

Bagian kelompok dari 8 atribut yang diperediksi memberikan pengaruh terhadap keberlanjutan pengelolaan Re-Opening Oil Wells Bojonegoro dari dimensi ecology yaitu; (1) Kualitas air permukaan, (kelompok baik $=3$, nilai $=0$ ), (2) Tingkat kualitas tanah, (kelompok baik $=3$, nilai $=0$ ) (3) Tingkat kesuburan tanaman (kelompok baik $=3$, nilai $=0)(4)$ Kerusakan lingkungan, (kelompok baik $=2$, nilai $=$ 1) (5) Kondisi berbukit, (kelompok baik $=3$, nilai $=1)(6)$ Cadangan minyak (kelompok baik $=3$, nilai $=$ 0) (7) Cadangan air permukaan, (kelompok baik $=2$, nilai $=1)(8)$ Peralatan ramah lingkungan (kelompok baik $=3$, nilai $=1$ ).

Dari hasil analisis keberlanjutan scale ordination dimensi ecology Rap-Re-Opening Oil Wells Kedewan Bojonegoro terlihat hasil indeks real ecology adalah sebesar $34,556 \%$ dan masuk dalam kategori kurang berkelanjutan $(<50)$.

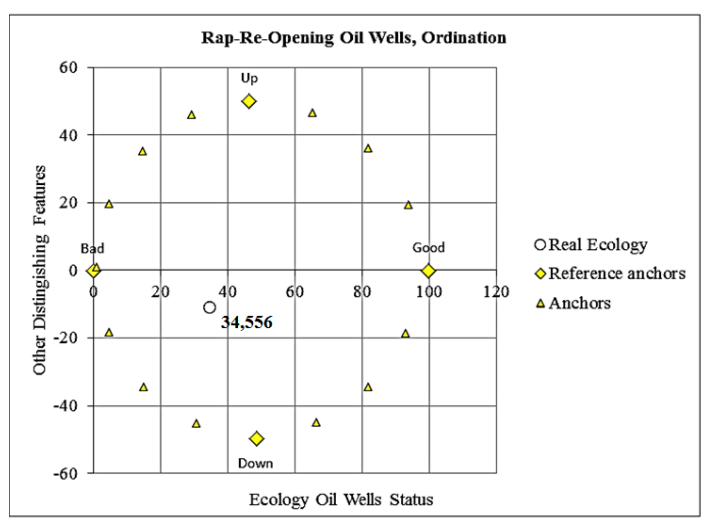

Gambar 4. Indeks Skala Ordinasi Berkelanjutan Dimensi Ekologi

Nilai persentasi tersebut menunjukkan bahwa kondisi ecology areal (Rap-Re-Opening Oil Wells) Bojonegoro mendapat tekanan dari aspek ecology. Kondisi ini terbukti dari fenomena dilapangan dari hasil 


\section{ZONA}

Jurnal Lingkungan

ISSN : 2502-6496 (Print) | 2502-6496 (Online)

survey menunjukkan telah terjadi pencemaran dengan lingkungan yang tak terkendali dari limbah yang berserakan disetiap areal sumur.

Selain mendapatkan indeks keberlanjutan, analisis Rap-Re-Opening Oil Wells juga menghasilkan keluaran berupa Laverage of Atributes atau bisa dikenal sebagai atribut pengungkit. Keluaran Lavarages of atributes bertujuan untuk memberikan informasi pengaruh terhadap indeks berkelanjutan pada dimensi ecology.

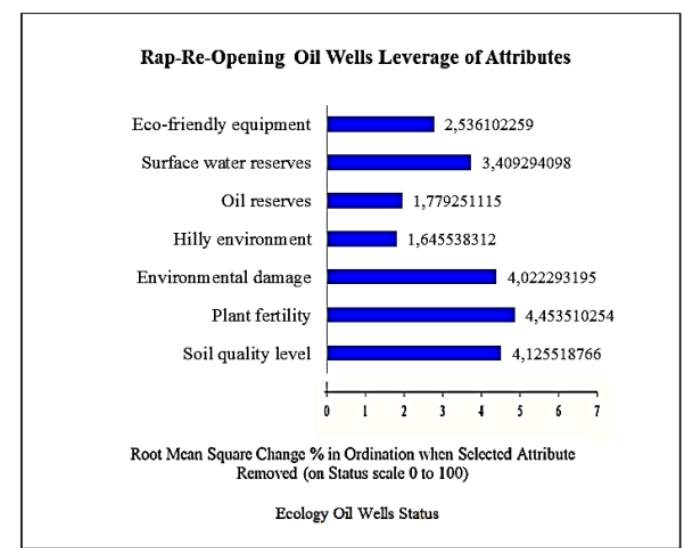

Gambar 5. Persentase Peran dari Masing-masing Atribut Aspek Dimensi Ekologi yang Dinyatakan Dalam Bentuk Nilai RMS (Root Mean Spuare)

Lavarages of atributes dimaksudkan untuk menggambarkan persentase nilai tertinggi dari fisheries keberlanjutan pada suatu dimensi keberlanjutan. Berdasarkan analisis laverage (Gambar 3) diperoleh tiga atribut yang sensitif terhadap nilai indeks keberlanjutan ecology yaitu, (1) tingkat kesuburan tanaman $(\mathrm{RMS}=4,453),(2)$ Tingkat kualitas tanah $(\mathrm{RMS}=4,125$, (3) kerusakan lingkungan $(\mathrm{RMS}=4,022$. Ketiga atribut ini memberikan sinyal bahwa atribut tersebut terindikasi berat terpengaruh dari aktifitas didaratan.

Kavanagh et al, (2004) mengatakan bahwa nilai RMS menunjukkan besarnya peran atribut terhadap sensitifitas pada status keberlanjutan. Dapat dikatakan bahwa semakin tinggi nilai RMS, maka akan semakin besar pengaruh dan peranan atribut tersebut terhadap sensitivitas keberlanjutan.

\section{Dimensi Ekonomi}

Atribut yang diperkirakan memberikan pengaruh terhadap dimensi economy ialah; (1) Tingkat pendapatan penambang (kelompok baik $=3$, nilai $=2)(2)$ Kelayakan taraf hidup penambang (kelompok baik $=2$, nilai $=1)(3)$ Kontribusi pendapatan daerah (kelompok baik $=2$, nilai $=1)(4)$ Ketersediaan peralatan (kelompok baik $=2$, nilai $=0)(5)$ Kontribusi Untuk Masyarakat (kelompok baik $=3$, nilai $=0$ ) (6) Biaya Pengelolaan Lingkungan (kelompok baik $=2$, nilai $=1)(7)$ Nilai Ekonomis (kelompok baik $=2$, nilai $=1)(8)$ Ketersediaan modal (kelompok baik $=3$, nilai $=2$ ).

Berdasarkan analisis Rap-Re-Opening Oil Wells terhadap dimensi ekonomi besaran persentase nilai berkelanjutan ialah; 39,728 \% sebagaimana terpapar pada gambar 6 Nilai tersebut menjelaskan status berkelanjutan pada dimensi ekonomi tersebut termasuk pada kategori kurang berlanjut $(<50)$ dalam rangka pengelolaan Re-Opening Oil Wells di kabupaten Bojonegoro tersebut. Nilai tersebut mengindikasikan adanya tekanan terhadap dimensi dari aspek ekonomi.

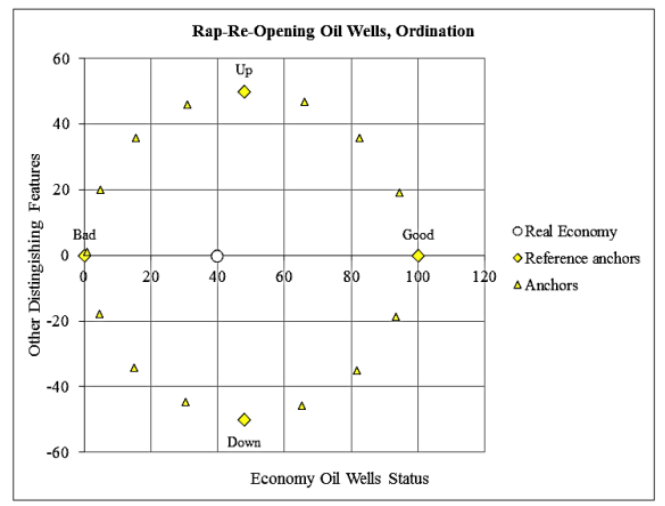

Gambar 6. Indeks Skala Ordinasi Berkelanjutan Dimensi Ekonomi 


\section{ZONA}

Jurnal Lingkungan

ISSN : 2502-6496 (Print) | 2502-6496 (Online)

Gambar 7 dibawah ini menjelaskan data tentang atribut-atribut yang spesifik dibandingkan dengan atrribut pada dimensi ekologi. Pada balok balok porsentase terlihat hampir berbanding lurus antara terminologi Up dan Terminologi Down dimana perbandingan untuk RMS (Root Mean Square) hanya terpaut pada angka nol koma (0,) untuk tiap-tiap atribut yaitu; (1) Ketersediaan modal RMS $=0,391 \%$ dan (8) Tingkat Pendapatan Penambang RMS $=0,382 \%$, (2) Nilai ekonomis RMS $=1,488 \%$ dan (7) Kelayakan taraf hidup penambang RMS $=1,430 \%$, (3) Biaya pengelolaan lingkungan RMS $=2,061 \%$ dan (6) Kontribusi PAD RMS $=2,061 \%$, (4) Kontribusi untuk masyarakat $\mathrm{RMS}=4,629 \%$ dan (5) Ketersedian peralatan RMS $=4,629 \%$

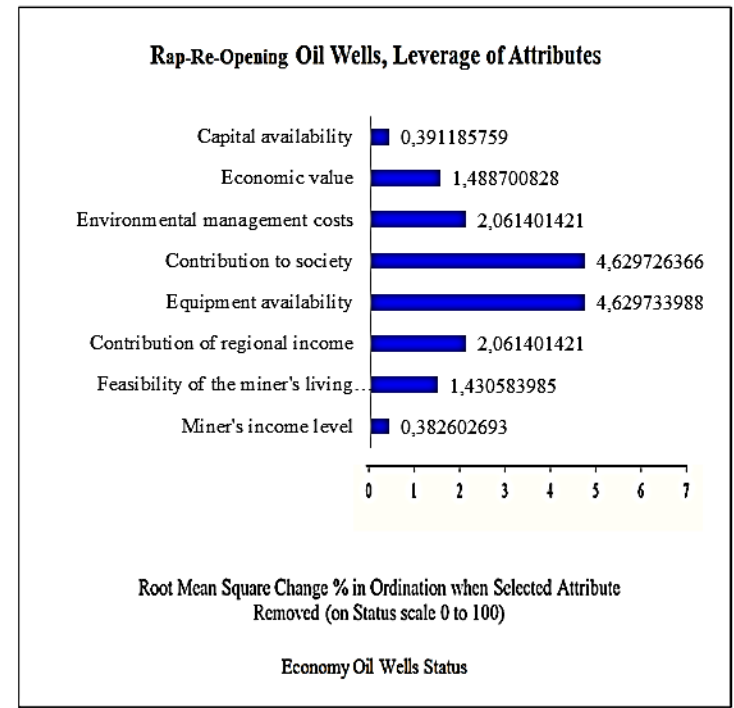

Gambar 7. Persentase Peran dari Masing-masing Atribut Aspek Dimensi Ekonomi yang Dinyatakan Dalam Bentuk Nilai RMS (Root Mean Spuare)

\section{Dimensi Sosial dan Budaya}

Atribut yang diperkirakan memberikan pengaruh keberlanjutan pada dimensi sosial dan budaya ialah; (1) Pemerataan hasil ke anggota penambang (kelompok baik $=3$, nilai $=3$ ) (2) Partisipasi masyarakat (kelompok baik $=3$, nilai $=0)(3)$ Tingkat ketrampilan tenaga kerja (kelompok baik $=2$, nilai $=$ 2) (4) Kearifan lokal (kelompok baik $=3$, nilai =0) (5) Pendidikan tentang pengelolaan penambangan persepsi stakeholders (kelompok baik $=2$, nilai $=1)(6)$ Konflik antara masyarakat penambang (kelompok baik $=3$, nilai $=1)(7)$ Pendidikan tentang pengelolaan lingkungan (kelompok baik $=3$, nilai $=1)(8)$ Pemerataan hasil ke masyarakat bukan penambang (kelompok baik $=3$, nilai $=1)$

Berdasarkan analisis MDS (Multidimension Scalling) terhadap Rap-Re-Opening Oil Wells Bojonegoro untuk dimensi sosial dan budaya menghasilkan nilai persentase ordinasi seperti gambar 7. Dari gambar tersebut untuk nilai dimensi sosial dan budaya terpapar nilai ordinasi sebesar $45,250 \%$, nilai ini menunjukkan bahwa dimensi sosial dan budaya masuk dalam kategori kurang berkelanjutan $(<50)$. Terhadap beberapa dimensi yaitu ekologi, ekonomi, dan sosial dan budaya untuk Re-Opening Oil Wells, masih belum ditemukan nilai berkelanjutan pada tahap cukup berkelanjutan. Nilai indeks keberlanjutan untuk RMS (Root Mean Square) leverage, pada analisis Rap-Re-Opening Oil Wells merupakan leverage atribut yang didominasi terhadap tiga atribut dimensi maksimum atribut sosial dan budaya yaitu; Kearifan lokal, keterampilan tenaga kerja, dan konflik penambang.

Nilai indeks keberlanjutan untuk RMS (Root Mean Square) leverage untuk dimensi sosial dan budaya sebagaimana terpapar pada gambar 7 yang merupakan faktor pengungkit didominasi dari tiga atribut dengan nilai maksimum ke minimum sebagai berikut; (1) Kearifan lokal RMS $=6,886 \%$, (2) keterampilan tenaga kerja RMS $=6,329 \%$, dan (3) konflik penambang RMS $=3,591 \%$. 


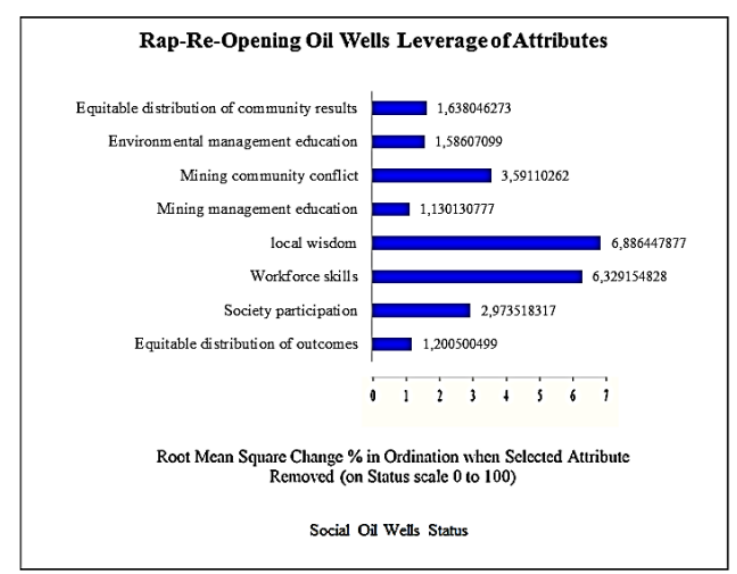

Gambar 8. Persentasi Peran dari Masing-masing Atribut Aspek Dimensi Sosial yang Dinyatakan Dalam Bentuk Nilai RMS Root Mean Spuare)

\section{Dimensi Teknologi}

Atribut yang diperkirakan memiliki pengaruh berkelanjutan terhadap dimensi teknologi ialah; (1) Selektifitas peralatan produksi (kelompok baik $=3$, nilai $=1)(2)$ Pengelolaan di lapangan (kelompok baik $=3$, nilai $=1)(3)$ Kapasitas peralatan produksi (kelompok baik $=3$, nilai $=1)(4)$ Penggunaan alat bantu dampak negatif (kelompok baik $=3$, nilai $=2$ ) (5) Alat keamanan bagi penambang (kelompok baik $=2$, nilai $=0)(6)$ Sarana penampungan di lapangan (kelompok baik $=2$, nilai $=0)(7)$ Penanganan pasca eksploitasi (kelompok baik $=2$, nilai $=1)(8)$ Penggunaan alat bantu teknologi $($ kelompok baik $=2$, nilai $=$ 1)

Hasil analisis menggunakan MDS (Multidimesional Scaling) menunjukkan hasil ordinasi persentase dimensi teknologi sebesar 37,895\% nilai ini mengindikasikan bahwa kondisi dimensi teknologi untuk ReOpening Oil Wells kurang berkelanjutan. Paparan kondisi dimensi ini dapat dilihat pada Gambar 9.

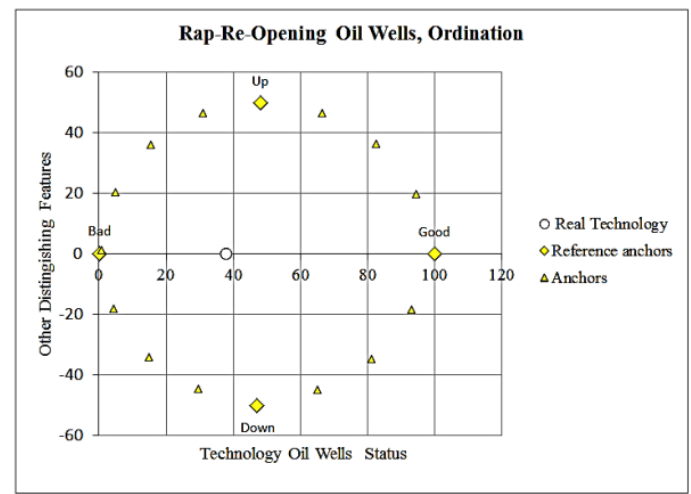

\section{Gambar 9. Indeks Skala Ordinasi Berkelanjutan Dimensi Teknologi}

Analisis Re-Opening Oil Wells yang juga menghasilkan keluaran leverange berupa laverange of attribut yang juga dikenal sebagai atribut pengungkit. Hasil analisis leverange bertujuan untuk melihat atributatribut yang sensitif memberikan nilai berkelanjutan pada dimensi teknologi.

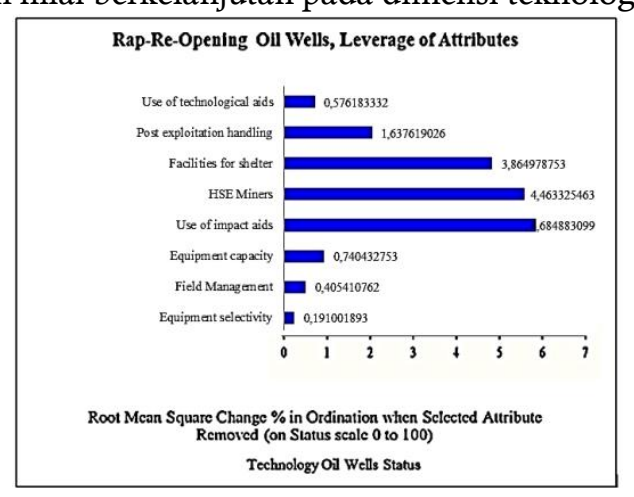

Gambar 10. Persentasi Peran dari Masing-masing Atribut Aspek Dimensi Teknologi yang Dinyatakan

Dalam Bentuk Nilai RMS (Root Mean Spuare) 


\section{ZONA}

Jurnal Lingkungan

ISSN : 2502-6496 (Print) | 2502-6496 (Online)

Volume 5, No 1, April 2021, p. 1-11

http://zona.pelantarpress.co.id

Berdasarkan dari tampilan gambar 9 leverange dapat kita lihat atribut yang berpengaruh berkelanjutan pada Re-Opening Oil Wells sebagai berikut; tiga dimensi yang signifikan mempengaruhi tingkat berkelanjutan (1) Penggunaan alat bantu dampak RMS $=4,684 \%$, (2) HSE Penambang RMS = $4,463 \%$, (3) Sarana penampungan RMS $=3,864 \%$.

\section{Dimensi Kelembagaan}

Atribut dimensi dasar pengelolaan pada sektor kelembagaan yang diperkirakan memiliki pengaruh terhadap dimensi kelembagaan ialah; (1) Efektifitas kelembagaan (kelompok baik $=3$, nilai $=1$ ) $(2)$ Aspek legalitas (kelompok baik $=3$, nilai $=3$ ) (3) Kebijakan hukum (kelompok baik $=2$, nilai $=2$ ) $(4)$ Koordinasi perangkat pemerintah daerah (kelompok baik $=3$, nilai $=1)(5)$ Fasilitas moril Penunjang Penambangan (kelompok baik $=2$, nilai $=1)(6)$ Zonasi peruntukan penambangan $(7)$ Bantuan daerah alat penambangan $($ kelompok baik $=2$, nilai $=0)(8)$ Kerjasama armada angkutan daerah $($ kelompok baik $=2$, nilai $=1)$

Hasil analisis menggunalan MDS (Multidimensional Scaling) pada Rap-Re-Opening Oil Wells terhadap beberapa dimensi, dimensi kelembagaan atau institusional memperlihatkan persentase nilai indeks sebesar 56,996\% artinya pada status dimensi kelembagaan untuk Re-Opening Oil Wells ini masuk dalam kategori cukup berkelanjutan karena berada diatas angka skor ordinasi 50\% (>50). Oleh karena itu keberadaan dan kondisi ini perlu mendapat perhatian dan peningkatan hingga mencapai status berkelanjutan selain upaya mempertahankan existing yang ada saat ini perlu ditingkatkan upaya upaya perbaikan secara menyeluruh terhadap sarana sarana penunjang dilapangan dan tindakan pemeliharaan secara berkala serta melakukan peningkatan kearah yang lebih baik lagi.

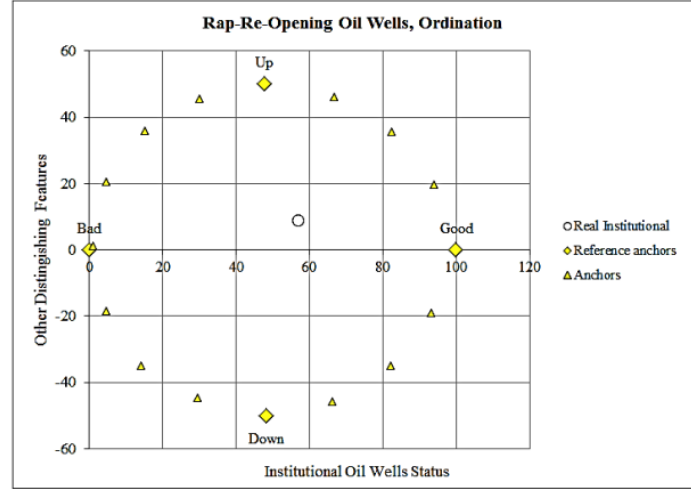

Gambar 11. Indeks Skala Ordinasi Berkelanjutan Dimensi Kelembagaan

Analisis Rap-Re-Opening Oil Wells dalam program MSD, menghasilkan nilai persentase leverange pada tiap-tiap atribut untuk dimensi kelembagaan ini. Nilai leverange ini merupakan nilai atribut yang diharapkan memiliki harapan untuk menuju posisi berkelanjutan pada Re-Opening Oli Wells Bojonegoro. Perhitungan kesesuaian MDS dengan besaran nilai stres sedangkan untuk validitas model ditunjukkan dengan besaran nilai koefisien diterminasi (R2) (Kavanagh dan Pitcher, 2004). Hasil analisis yang dapat mempresentasikan model dengan baik ditunjukkan dengan nilai stres dibawah 0,25 dan R2 yang berhenti 1 atau 100 persen

Dari hasil leverange pada gambar 11 memperlihatkan diagram balok yang hampir merata dan didominasi tiga balok untuk atribut cukup berkelanjutan yaitu; (1) Kebijakan hukum RMS $=5,901 \%$, (2) Koordinasi pemangku kepentingan RMS $=5,571 \%$, (3) Zonasi wilayah penambangan RMS $=5,290 \%$. Kavanagh dan Pitcher (2004) mengatakan bahwa nilai RMS menunjukkan besarnya peran atribut terhadap sensitifitas pada status keberlanjutan. 


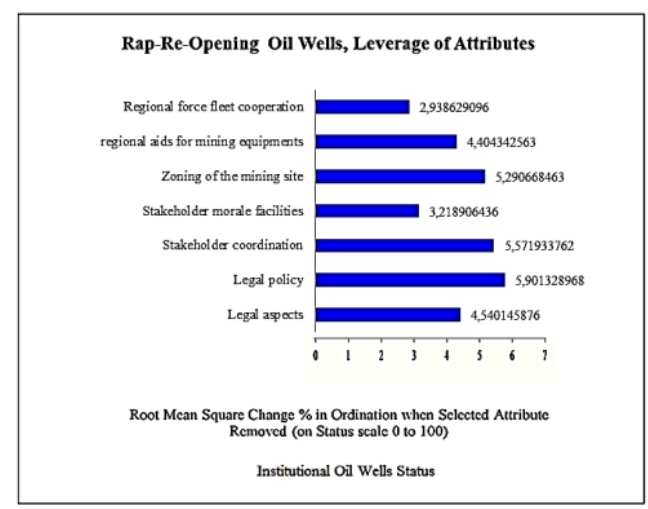

Gambar 12. Persentasi Peran dari Masing-masing Atribut Aspek Dimensi Kelembagaan yang Dinyatakan Dalam Bentuk Nilai RMS (Root Mean Spuare)

\section{Status Keberlanjutan Multidimensi}

Hasil pembahasan berdasarkan analisis menggunakan metode Rap-Re-Openging Oil Wells sebagaimana terpapar diatas memperlihatkan nilai indeks ordinasi keberlanjutan yang tidak seragam dari masing-masing dimensi. Dalam hasil analisis terdapat hampir $90 \%$ dimensi berada pada kategori kurang berkelanjutan dan lebih kurang $10 \%$ baru mencapai cukup berkelanjutan.

Empat dimensi yang tergolong kurang berkelanjutan adalah dimensi ekologi RMS $=34,556 \%$, dimensi ekonomi RMS $=39,728 \%$, dimensi sosial RMS $=45,250 \%$ dan dimensi teknologi $\mathrm{RMS}=$ $37,895 \%$. Sementara nilai porsentase $10 \%$ yang merupakan kategori cukup berkelanjutan adalah dimensi kelembagaan dengan angka RMS $=56,996 \%$.

Dari hasil Program MDS yang terlihat dari masing-masing dimensi menjelaskan bahwa pelaksanaan Re-Opening Oil Wells Bojonegoro masih terkelola secara tradisional dan dengan teknologi sederhana. Implementasi nilai 10\% dari dimensi kelembagaan mencerminkan hanya karena adanya faktor ketaatan aparatur pemangku kepentingan terhadap peraturan dan perundangan yang berlaku. Paparan diagram untuk Re-Opening Oil Wells tergambar pada gambar 12 berikut;

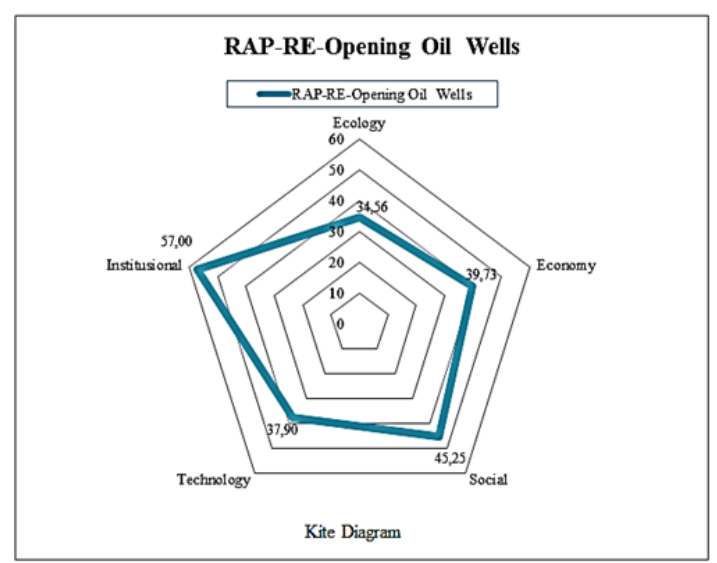

Gambar 13. Diagram Layang Analisis Indeks dan StatusKeberlanjutan Re- Opening Oil Wells Bojonegoro

Perubahan kondisi yang akan datang terhadap faktor kunci pengelolaan Re-Opening Oil Wells, terpapar dalam bentuk interaksi antara lima atribut faktor kuinci berdasarkan hasil analisis data perspektif yaitu; (1) Kearifan lokal 41,44 \%, (2) Ketersediaan Peralatan 61,62 \% (3) Tingkat Kualitas tanah 45,25 (4) Keterampilan tenaga kerja 42,02\% dan (5) Kontribusi ke masyarakat 61,29\%. yang dapat di gambarkan dalam fungsi sebagai berikut: $\mathrm{S}-\mathrm{ROW}=\mathrm{f}(\mathrm{Lw}, \mathrm{t}, \mathrm{s}, \mathrm{Sf}, \mathrm{c})$ Dimana; $(\mathrm{S}-\mathrm{ROW})=$ Sustainable ReOpening Oil Wells, $(\mathrm{Lw})=($ Local wisdom $),(\mathrm{t})=($ tools $),(\mathrm{s})=$ Skill,$(\mathrm{Sf})=$ Soil fertility, $(\mathrm{c})$ Contribution . 


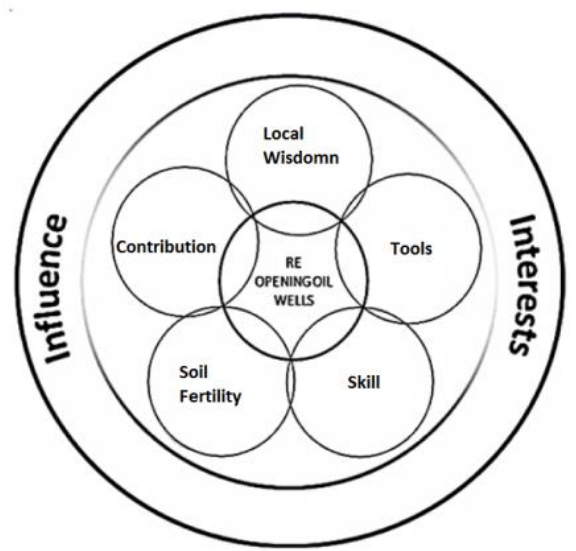

Gambar 14. Persamaan Fungsi S-ROW $=\mathrm{f}(\mathrm{Lw}, \mathrm{t}, \mathrm{s}, \mathrm{Sf}, \mathrm{c})(\mathrm{S}-\mathrm{ROW})=$ Sustainable Re-Oil Wells, $(\mathrm{Lw})=$ (Local wisdom), $(\mathrm{t})=($ tools $),(\mathrm{s})=$ Skill, $(\mathrm{Sf})$ Soil fertility, $(\mathrm{c})$ Contribution .

\section{KESIMPULAN}

Berdasarkan analisis yang dilakukan dengan menggunakan pendekatan uji material di laboratorium dan menggunakan metode multidimensi Rapfish, disimpulkan bahwa Re-Opening Oil Wells Bojonegoro Jawa Timur telah menimbulkan dampak terhadap beberapa dimensi yang bernilai positif dan negatif. Dampak positif terjadinya peningkatan produksi minyak secara nasional, tingkat ekonomi masyarakat, dan kesejahteraan sosial sementara pada sisi negatif terjadi pencemaran lingkungan yang menyebabkan menurunya tingkat produktifitas lahan pertanian dan perikanan dengan tingkat keberlanjutan rendah yang ditunjukkan dari angka analisis keberlanjutan dengan model $S$-ROW $=\mathrm{F}(L w+s+t+S f+c)$ merupakan interaksi dan afiliasi dari lima kondisi yaitu; kearifan lokal, keterampilan tenaga kerja, ketersediaan peralatan, tingkat kualitas tanah, dan kontribusi untuk masyarakat yang berbasis pengaruh dan kepentingan

\section{DAFTAR PUSTAKA}

Broman, G. I., \& Robert, K.-H. (2015). A Framework for Strategic Sustainable Development. Journal of Cleaner Production Carrying capacity as a basis for sustainable development: a case study of the National Capital Region in India.

Huang, C.-J., \& Ho, Y.-H. (2017). Governance and economic growth in Asia. The North American Journal of Economics and Finance, 39(100), 260-272. https://doi.org/10.1016/j.najef.2016.10.010

J. F. Willis et al., J.F.Willis A. J. Minden J.C.Snyder MONTE CARLO SIMULATION OF MANAGEMENT SYSTEMS. First published: February 1969. https://doi.org/10.1111/j.17447976.1969.tb02468.x

Kavanagh, P, and Tony J. Pitcher. (2004). Kavanagh, P, and Tony J. Pitcher Implementing Microsoft Excel Software For Rapfish: A Technique for the Rapid Appraisal of Fisheries Status. The Fisheries Center, University of British Columbia, 2259 Lower Mall. Fisheries Center Research Reports 12 (2).

Kavanagh, P., and Pitcher, T.J., (2004) Kavanagh, P., and Pitcher, T.J., 2004 Implementing Microsoft Excel Software for RAPFISH: A Technique for The Rapid Appraisal of Fisheries Status. The Fisheries Center, University of British Columbia, 2259 Lower Mall Vancouver, Canada, V6T IZ4.

Mark J. Et al., (2008) Mark.J Kaiser, Richard D.Dodson Trends in plug and abandonment cost in the Gulf of Mexico, 2002-2007 International Journal of Oil, Gas and Coal Technology (IJOJCT), Vol.1.No.1/2.2008 Minister of Energy and Mineral Resources Number 01 of 2008 concerning "Guidelines for the Exploration of Petroleum Mining in Old wells" Republic of Indonesia

Patricia Kavanagh and Tony J. Pitcher (2004) Patricia Kavanagh and Tony J. Pitcher Fisheries Centre Research Reports. 12(2) 75 pages (C) published 2004 by The Fisheries Centre, University of British Columbia, 2259 Lower Mall Vancouver, B.C., Canada, V6T 1Z4 


\section{ZONA}

Jurnal Lingkungan

ISSN : 2502-6496 (Print) | 2502-6496 (Online)
Volume 5, No 1, April 2021, p. 1-11 http://zona.pelantarpress.co.id

Rasic, K., Mulej, M., \& Cancer, V. (2012). The System of Indicators of Economic Growth for Better Quality of Life: Economic and Social Impacts, 31, 535-562.

Rita Parmawati, (2019) Rita Parmawati SUSTAINABLE MANAGEMENT RURAL AGROPOLITAN DEVELOPMENT IN SENDANG OF TULUNG AGUNG, EAST JAVA A MULTIDIMENTIONAL ANALYSIS OF SUSTAINABILITY. Vol. 9 No.3. (2019)

Todaro, M. P., \& Smith, S. C. (2011a).Pembangunan Ekonomi Jilid I (11th ed.). Jakarta: Erlangga.

Todaro, M. P., \& Smith, S. C. (2011b). Pembangunan Ekonomi Jilid II. (A. Maulana, Ed.) (11 ${ }^{\text {th }}$ ed.). Jakarta: Penerbit Erlangga.

Tony J. Pitcer, (2001) Tony J. Pitcer RAPFISH: A Rapid Appraisal Technique to Evaluate the Sustainability Status of Fisheries. British University Columbia. Vancouver.Fisheries Research 49(3):255-270

Van den Bergh, J. C. J. M., \& Kallis, G. (2012). Growth, A-Growth or Degrowth to Stay within Planetary Boundaries? Journal of Economic Issues, 46(4), 909-920.https://doi.org/10.2753/JEI0021-3624460404

Walkowiak, E. (1996). Sustainable development as an economic development strategy. Economic Development Review, 75-77. 